\title{
Organizational Performance in Sme's Industry Jepara
}

\author{
$1^{\text {st }}$ Dasmadi \\ Fakultas Ekonomi \\ Universitas Sultan Agung Semarang \\ Indonesia \\ rara@unwahas.ac.id
}

\author{
$2^{\text {nd }}$ Ratih Pratiwi \\ Fakultas Ekonomi \\ Universitas Sultan Agung Semarang \\ Indonesia
}

\author{
$3^{\text {rd }}$ Yulekhah Ariyanti \\ Fakultas Ekonomi \\ Universitas Wahid Hasyim Semarang \\ Indonesia
}

\begin{abstract}
Small and Medium Enterprises (SMEs) is one of the Central Java 7\% revenue supporting factor in 2021. Small and Medium Enterprises (SMEs) is a high potential sector to be developed. Activities of SMEs in the Jepara Residency will affect in many PAD supporting sectors such as raw material providers, craftsmen, tourism, trade, industry, transportation and other related sectors. This study aims to analyze the effect of Collaborative Agility and Intellectual Stimulation Leadership on Organizational Performance with Creativity Engagement as a mediating variable. This research was conducted in Jepara, Kudus and Rembang on craftsmen from 87 SMEs, data obtained using SEM PLS software. The results showed that Collaborative Agility has not significant relationship in SMEs performance, and will improve the performance through Collaborative Agility as a mediating variable. In influencing the optimal performance achievements SMEs requires creativity engagement and intellectual stimulation leadership whose can motivate and inspire their subordinates by communicating high hopes and clear work struggles. Creativity engagement is moved by collaborative agility and intellectual stimulation leadership. Creativity Engagement has a large influence on SME Performance. The limitation and implication is discussed as follow.
\end{abstract}

Keywords-SMEs Performance, Collaborative Agility, Intellectual Stimulation Leadership, Creativity Engagement

\section{INTRODUCTION}

Small and Medium Enterprises (SMEs) currently have a significant role in national economic development, from its contribution to Indonesia's Gross Domestic Product (GDP) which continues to be increased in every year [1]. Based on the results of surveys and calculations by the Central Statistics Agency (BPS), the contribution of SMEs to Indonesia's GDP continues to increase every year.

Indonesia National Planning And Research Departement in 2019 stated that SMEs became the foundation for $99.45 \%$ of the workforce in Indonesia and also be able to open new jobs for 9.6 million people, while large businesses are only able to open new jobs for 55,760 people. Therefore, the growth of SMEs in Indonesia is important to expand employment opportunities and provide broad economic services to the community. SMEs plays important role in the process of equity and increases people's income, encourage economic growth and play a role in realizing national stability in general and economic stability [2].

Factors to develop SMEs are the availability of local raw materials, human capital, skills, and market opportunity [3]. The working capital needed is relatively small, thus providing an opportunity for people who have an entrepreneurial spirit to establish business units with a level of sophistication of affordable production techniques [4]. Within certain limits, small and medium industrial activities can reduce some of the import burdens so that within the strategic framework, this can save foreign exchange. In line with the Indonesian government's economic development program, where Central Java priority program is focused at improving welfare and alleviating poverty through empowering the people's economy, it is estimated that in 2020 Central Java will foster to $7 \%$ economic growth rate [5].

The development of new entrepreneurs is related to foster a conducive business environment, fostering the willingness of the community to be entrepreneurs, enhancing the ability of the community to be entrepreneurs [6]. The SMEs are business activities that are able to expand employment opportunities and provide broad economic services to the community that can play a role in the process of equity and increase people's income, and encourage economic growth and play a role in realizing national stability in general and economic stability in particular [7].

Leadership is an important factor to determine employee performance and organizational ability in adapting environment changes [8]. Leadership describes the relationship between the leader with the follower and how a leader directs the follower will determine the extent to which the follower reaches the goals or expectations of the leader [9]. The transformational leadership develop and support the potential and ability to achieve or even exceed organizational goals [10]. A leader can transform his subordinates through four ways [11] those are 
Idealized Influence (Charisma), Inspirational Motivation, Intellectual Stimulation and Intellectual Stimulation. Intellectual Stimulation is a part of transformational leadership leader who practices innovations [12]. His leadership attitude and behavior is based on developing science and intellectual and able to translate it in the form of productive performance [13].

The Collaborative Agility influence stakeholder involvement, where agility includes the ability of the company to deal with customer interactions, internal operating agility and interactions with external business partners [14] and that agility includes exploration and exploitation of market opportunities [15]. Collaboration means achieving common goals by helping one and another [16]. Collaboration will have an impact on stakeholder involvement, where collaboration involves the division of tasks, where everyone does every job [17]. In the public sector, collaboration can be understood as a process of togetherness, cooperation, sharing of tasks, equality, and responsibility between several entities whose activities are connected [18].

SMEs characteristics in general have limited sources of funding, management, and depend on a small number of customers [19]. SMEs also needs multiskill employees [20]. SMEs continue to make improvements both in the production process, product quality, and service in order to be able to survive and compete with large companies [21] Creativity is the main key to develop new ideas from existed ideas and meets the consumers needs [22]. One of the strategies to improve competitiveness is that companies must be oriented to creativity and innovation [23]. Creativity is one of the three main functions of human reason [24]. Two other functions are analytical power and assessment power [23]. Creativity has the ability to develop new ideas from the ideas that have been held and subsequently to form useful innovations [25]. Creativity is a supporting part of the existence of one's life. Everyone has creativity, and what make difference is their level of creativity. And these differences are important in this highly competitive world. The importance of creativity are the ability to be creative towards new challenges, together with an ability to anticipate developments and be innovative [23].

The activities of SMEs in Jepara has so many impacts in many parties (such as raw material providers, craftsmen, government, exporters, importers and other related parties), it show the importance of stakeholders to improve the performance of SMEs in Jepara. Jepara is the word carving city and been famous with the creativity of its citizens. The informal sector such as SMEs plays an important role in improving the welfare of the community, and labor absorption. however the presence of SMEs has not been able to provide an optimal impact in increasing economic growth in Jepara district. To improve the SME sector this article proposes to unite the creativity of existing resources by collaborating on agility and the role of intellectual stimulation leadership.

This study purposes to prove that how to improve the SMSs performance through Creativity Engagement,
Collaborative Agility and Intellectual Stimulation Leadership.

\section{LITERATURE REVIEW}

A. Collaborative Agility

Collaboration is the mutual cooperation of the participants in a coordinated effort to resolve shared problems [16]. Collaborative interaction is characterized by shared goals, structural symmetry, and high-level negotiation, interactivity, and interdependence [17].

Agility includes the company's capabilities related to customer interactions, internal operating agility and interactions with external business partners [17]. Agility includes exploration and exploitation of market opportunities [26]. Agility consists of three sub-constructs of interrelated capabilities, namely customer agility, collaborative agility (Partnering Agility/ PA), and operational agility (OA) [27]. Agility is the managerial ability to quickly adapt and change both organizational structures and culture, integrate processes quickly and redesign existing processes and create new processes to exploit dynamic markets [15].

Collaboration is the mutual cooperation of the participants in a coordinated effort to solve joint problems [14]. Collaborative interaction is characterized by shared goals, structural symmetry, and high-level negotiation, interactivity, and interdependence [18]. Collaboration means working together to achieve common goals as a basic social process [15]. Collaboration involves the division of tasks, where each person does every job that is his responsibility for the achievement of common goals [14].

In the public sector for example, collaboration can be understood as a process of togetherness, cooperation, sharing of tasks, equality, and responsibility among several entities whose activities are connected [28]. The parties who become entities in collaboration can be from government, civil society, and the private sector [14]. The main objective in public sector collaboration is aimed at improving services to the community. The definition explains that collaboration is a joint involvement in coordinated efforts to solve problems together. Collaborative interaction is characterized by shared goals, a symmetrical structure with high-level negotiations through intertivity and interdependence [18].

Collaboration has 8 (eight) characteristics, those are: participation is not restricted and not hierarchical, participants are responsible for ensuring the achievement of success, reasonable goals, problem definition, participants educate each other or teach one another identification and testing of sharing choice, the implementation of the solution is shared with several participants involved, and participants are always aware of the development of the situation [29]. The collaboration agility is measured by agility in human relations dexterity results, mental agility and dexterity changes.

In order thrive the organizational collaboration reach the purposes, the collaborator (the party involved in the collaboration) must pay attention to several cultural components [18], leadership [18] [14], the strategy to be used [15], the teams involved and the safety network [26]. 
Collaboration enables firms to cultivate performance benefits through proactive coordination among divergent constituents [27]. The increased agility generally has a positive effect on the performance [28]. Thus, the hypothesis proposed are:

H1 : Collaborative agility has significant effect on Creativity Engagement

$\mathrm{H} 2$ : Collaborative agility has significant effect on Performance

\section{B. Intellectual Stimulation Leadership}

Intellectual Stimulation Leadership is a leader who practices innovations [29]. His leadership attitude and behavior is based on developing science and intellectually he is able to translate it in the form of productive performance [30]. Leaders always explore new ideas and creative solutions from staff and always encourage staff to learn and practice new approaches to doing work. Intellectual Stimulation is leader's attitude in show new ways of completing tasks and encourage employees to be more innovative, and invite employees to look at problems from the point of view and find new ways to solve problems [31]. The leader shows about new ways of completing tasks and encourages employees to be more innovative, and invites employees to look at problems from different points of view and find new ways of solving problems [32].

Transformational leaders strive to create a climate that is conducive to the development of innovation and creativity [9]. The leader encourages subordinates to come up with new ideas and creative solutions to the problems they face [33]. For this reason, subordinates are truly involved and empowered in the process of problem formulation and finding solutions [34]. Basically the essence of transformational leadership is sharing of power which involves subordinates together to make changes [10].

The results showed transformational leadership has a significant and positive influence on creativity engagement [22]. In line with the research revealed that transformational leadership influences engagement [35]. Intellectual stimulation is measured with learning styles, ability to think, involving ideas, cognitive styles dan thinking styles.

The results showed a significant and positive influence of transformational leadership on lecturer performance [36]. The previous literature shows that transformational leadership behavior plays a key role in improving the performance of employee [37]. Intellectual stimulation leadership has a significant impact on improving performance [32]. Thus, the hypothesis proposed are:

H3: Intellectual stimulation leadership has significant effect on Creativity Engagement

H4: Intellectual stimulation leadership has significant effect on Performance

\section{Creativity Engagement}

Creativity is a process of creating new and synergistic combinations of entities that seem unrelated [35]. Creativity that focuses on the individual or person of an individual who can be called creative [24]. Creativity is an ability or a skill that is in a person, this is closely related to talent [38]. Creativity is define as a process that focuses on thinking processes so as to bring up unique and creative ideas [39]. Creative process engagement is defined as individual's involvement in creativity-relevant processes or methods, consisting of problem identification, information searching and encoding, and idea and alternative generation [39]. The creative process engagement is can be defined as the creative process whereby individuals come to develop creative ideas [38]. Creative process engagement can enhance the potential for creative and innovative outcomes, and possibly result in increased overall performance [39]. To measure creative process engagement we use three dimensions: Problem identification, information searching, and idea generation [39].

Though creative process engagement will allows employees to think and deal with tasks creatively to produce novel and useful solutions to problems and this engagement will influence employees performance [25].

H5: Creativity Engagement has significant effect on Performance

\section{SME's Performance}

Performance is the result of work that can be achieved by a person or group of people in the organization, in accordance with the authority and responsibilities of each in order to achieve organizational goals [28]. Performance or is the achievement or achievement of a person regarding the tasks assigned to him [40]. Performance is can be said as a function of ability, effort and support by an human resources [41].

Performance is what can be done by someone in accordance with the tasks and functions [25]. Performance is everything that someone does and results in carrying out the function of a job [6].

So it can be concluded that Performance is the quantity and quality of achieving tasks, whether carried out by individuals, groups or organizations. Performance SMEs measured by feedback, assessment of organizational progress, Performance is measured by the indicators those are Quality, Quantity, Cost effectiveness, Need for superfision dan Interpersonal Impact [37].

H6: Collaborative Agility influence the Organizational Performance with Creativity Engagement as a mediating variable

H7 : Intellectual Stimulation Leeadership influence the Organizational Performance with Creativity Engagement as a mediating variable.

\section{MEASUREMENT METHODS}

This research type is Explanatory Research that emphasizes the relationship between research variables (causality) by testing the description of the hypothesis containing description but the focus lies in the relationship between variables. Variables include: Collaborative Agility, Intellectual Stimulation Leadership, Creativity Engagement dan Organizational Performance.

Data collection techniques were carried out in this study using a questionnaire, which is a list of questions given to owners/ entrepreneurs of SMEs in Jepara Regency. The sampling method using census techniques is 87 SMEs owners in Jepara. The sampling technique uses 
census. Data obtained from the distribution of questionnaires using a Likert scale, analyzed with SEM PLS software.

Performance is measured by the indicators those are quality, quantity, cost effectiveness, need for superfision dan interpersonal Impact. To measure creativity process engagement we use three dimensions: problem identification, information searching, and idea generation [39]. Intellectual stimulation leadership is measured with learning styles, ability to think, involving ideas, cognitive styles dan thinking styles. The collaborative agility is measured by agility in human relations dexterity results, mental agility and dexterity changes.

\section{DATA ANALYSIS}

Data analysis was performed to test the validity of each indicator and the reliability of the construct. Validity criteria are measured by discriminant and convergent validity, while construct reliability is measured by composite reliability. This test is done using convergent size and discriminate validity on PLS. Validity test is used to measure the validity or validity of a questionnaire. A questionnaire is said to be valid if it is able to reveal something that will be measured by the questionnaire.

From the results of loading factor the convergent validity value of each indicator is an average $>0.5$ where for the value of 0.5 in the initial study is already a high value and if further research the value of each indicator > 0.7 .

TABLE I. RESULT OF RESEARCH VALIDITY VARIABLES

\begin{tabular}{|c|c|c|c|c|}
\hline & $\begin{array}{l}\text { Collaborative } \\
\text { Agility_(x1)_ }\end{array}$ & ISL_(x2)_ & $\begin{array}{c}\text { Creativity } \\
\text { Engagement_(y1) }\end{array}$ & SMEs Performance_(y2) \\
\hline $\mathrm{x} 1.1$ & 0.793 & & & \\
\hline $\mathrm{x} 1.2$ & 0.543 & & & \\
\hline $\mathrm{x} 1.3$ & 0.783 & & & \\
\hline $\begin{array}{l}\mathrm{x} 1.4 \\
\end{array}$ & 0.824 & & & \\
\hline $\begin{array}{l}\mathrm{x} 2.1 \\
\end{array}$ & & 0.608 & & \\
\hline $\mathrm{x} 2.2$ & & 0.655 & & \\
\hline $\mathrm{x} 2.3$ & & 0.646 & & \\
\hline x2.4 & & 0.651 & & \\
\hline $\mathrm{x} 2.5$ & & 0.830 & & \\
\hline $\mathrm{y} 1.1$ & & & 0.603 & \\
\hline $\mathrm{y} 1.2$ & & & 0.835 & \\
\hline $\mathrm{y} 1.3$ & & & 0.855 & \\
\hline y2.1 & & & & 0.793 \\
\hline $\mathrm{y} 2.2$ & & & & 0.243 \\
\hline$y 2.3$ & & & & 0.783 \\
\hline y2.4 & & & & 0.824 \\
\hline y2.5 & & & & 0.596 \\
\hline
\end{tabular}

Reliability measurement using 2 (two) ways :

TABLE II. COMPOSITE RELIABILITY VALUE

\begin{tabular}{|l|c|c|}
\hline & AVE & Composite Reliability \\
\hline Collaborative agility & 0.698 & 0.780 \\
\hline Intellectual stimulation leadership & 0.690 & 0.791 \\
\hline Creative engagement process & 0.597 & 0.813 \\
\hline SMEs performance & 0.916 & 0.956 \\
\hline
\end{tabular}

Table II shows the results of the composite reliability of all variables have a composite reliability value $>0.7$ means that it has a good reliability value and can be used for further research processes. Average Variance Extracted obtained has a value $>0.5$, from the results above all variables have an Average Variance Extracted value $>0.5$ meaning that it has a good reliability value and can be used for further research processes. To determine whether a hypothesis is accepted or not by comparing tcount with ttable with the condition if $t_{\text {count }}>$ $\mathrm{t}_{\text {table, then }}$ the hypothesis is accepted. For more details can be seen in Table 3 below. 
TABLE III. HYPOTHESIS TESTING TABLE

\begin{tabular}{|l|r|r|r|r|r|}
\hline & $\begin{array}{c}\text { Original } \\
\text { Sample (O) }\end{array}$ & Sample Mean (M) & $\begin{array}{c}\text { Standard Deviation } \\
(\text { STDEV) }\end{array}$ & $\begin{array}{c}\text { T Statistics } \\
(|\mathrm{O} / \mathrm{STDEV}|)\end{array}$ & $\begin{array}{c}\text { P Values } \\
\mathrm{X} 1 \rightarrow \mathrm{y} 2\end{array}$ \\
\hline $\mathrm{X} 1 \rightarrow \mathrm{y} 1$ & -0.070 & -0.067 & 0.068 & 0.064 & 0.303 \\
\hline $\mathrm{X} 2 \rightarrow \mathrm{y} 2$ & 0.329 & 0.330 & 0.091 & 0.170 & 0.000 \\
\hline $\mathrm{X} 2 \rightarrow \mathrm{y} 1$ & 0.554 & 0.574 & 0.047 & 0.03 & 0.000 \\
\hline $\mathrm{Y} 1 \rightarrow \mathrm{y} 2$ & 0.653 & 0.661 & 0.094 & 0.000 \\
\hline
\end{tabular}

Then the structural equation model formed according to table III are:

Equation $1: \mathrm{Y}_{(1)}=0,329 \mathrm{X}_{1}+0,653 \mathrm{X}_{2}+e$

Equation $2: \mathrm{Y}_{(2)}=-0,070 \mathrm{X}_{1}+0,554 \mathrm{X} 2+0,347 \mathrm{Y}_{1+} e$

The results of data processing above can be known in testing each hypothesis that has been proposed. The first hypothesis, the effect of collaborative agility on the performance of SMEs is rejected. So it can be concluded that collaborative agility does not have a significant effect on improving HR performance. The second hypothesis is the effect of collaborative agility on creativity engagement is accepted. So it can be concluded that the higher collaboration SMEs so it will increase creativity engagement. The third hypothesis is the effect of intellectual stimulation leadership on the performance of SMEs is accepted. The higher intellectual stimulation leadership will improve the performance of SMEs. The fourth hypothesis is the influence of intellectual

stimulation leadership on creativity engagement is accepted. So it can be concluded that the higher intellectual stimulation leaderhip will increase creativity engagement. The fifth hypothesis is that the effect of creativity engagement on the performance of SMEs is accepted. So it can be concluded that there is a significant positive influence on creativity engagement on the performance of SMEs.

Assessing the inner model is evaluating the relationship between latent constructs as hypothesized, where the relationship of each construct is measured by 2 latent constructs. As illustrated in the results of the following R-square values.

\begin{tabular}{|l|l|}
\hline \multicolumn{1}{|c|}{ TABLE IV. R-SQUARE (R2) VALUE } \\
\hline Creativity Engagement & R Square \\
\hline Performance & 0,506 \\
\hline
\end{tabular}

Based on the $\mathrm{R}$ square value shows that the variation of SMEs performance can be explained by collaborative agility, creativity engagement and intellectual stimulation leadership by $75.5 \%$ and the remaining $24.5 \%$ is explained by variations of other variables not included in the model. Variation of creativity engagement can be explained by collaborative agility and intellectual stimulation leadership by $50.6 \%$, the remaining $49.4 \%$ is explained by variations of other variables not included in the model.

Analysis of direct, indirect and total effects is intended to determine the effect of the hypothesized variable. The direct effect is the coefficient of all coefficient lines with one end arrow or often called the path coefficient, while the indirect effect is the effect caused by an intermediate variable. Whereas total influence is the total multiplication of direct and indirect influences.

TABLE V. DIRECT AND INDIRECT EFFECT

\begin{tabular}{|l|l|l|}
\hline \multicolumn{1}{|c|}{ Relationship } & Coefficient & \multicolumn{1}{c|}{ explanation } \\
\hline Direct Effect of collaborative agility to SMEs Performance & 0.070 & Unsignificant \\
\hline $\begin{array}{l}\text { Indirect Effect of collaborative agility to SMEs Performance trough } \\
\text { creativity engagement }(0,329 \times 0,347)\end{array}$ & 0,114 & Mediating Effect \\
\hline Direct Effect intellectual stimulation leadership to SMEs Performance & 0,554 & Significant \\
\hline $\begin{array}{l}\text { Indirect Effect intellectual stimulation leadership to SMEs Performance } \\
\text { trough creativity engagement }(0,536 \times 0,347)\end{array}$ & 0,186 & Not Mediating Effect \\
\hline
\end{tabular}

From Table $\mathrm{V}$ it is known that the direct effect of collaborative agility on SMEs performance (0.070) is smaller $(<)$ than indirect effect of collaborative agility on SMEs performance through creativity engagement (0.114). So it can be seen that collaborative agility affects performance indirectly, and the creativity engagement variable is an intervening/ mediating variable. The first model to improve the performance of SMEs, organizations must improve collaborative agility and creativity engagement properly. Direct Effect of intellectual stimulation leadership on SMEs performance $(0.554)$ is bigger than $(>)$ the Indirect Effect of intellectual stimulation leadership on SMEs performance through creativity engagement (0.186). Intellectual stimulation leadership directly affects the performance of SMEs, the creativity engagement variable is not an intervening variable in this connection. The second model of SMEs performance improvement, organizations must increase intellectual stimulation leadership.

\section{DISCUSSION}

The first hypothesis is that the effect of collaborative agility on the performance of SMEs is rejected. So it can be concluded that collaborative agility does not have a significant effect on improving HR performance in SMEs. Basically the goal of collaborative is to achieve common 
goals by helping one another. Collaboration is a form of social process, in which there are certain activities aimed at achieving common goals by helping each other and understanding each other's activities [28]. Collaboration in the public sector can be done with efforts to produce public goods and services in order to meet the needs and rights of the public where the collaborating parties have the same goal. Therefore, the collaboration contains about how common perceptions, willingness to process, mutual benefit, honesty, and prioritizing interests based on the community or consumers. While the concepts are not new, together they provide a framework for the deployment of an agile organization that is more responsive to the external environment [42]. How the organization goes about employing the measures relating to each attribute should vary according to the needs of the organization itself [43]. Though the common perceptions, willingness, mutual benefit, honesty, and interests of the community or consumers may vary, SMEs find difficulties to collaborate their resources to meet the hihgly turbulent environtment. The concept of organizational agility has its roots in two prior related concepts: organizational adaptability (a reactive aspect) and organizational flexibility (a proactive aspect) [44]. Organizational agility involves a firm's ability to sense environmental changes (sensing) and to respond readily to them (responding) by reconfiguring its resources, processes, and strategies [43]. While the SMEs does not ready to reacting rapidly to change, and can't recognize their organization's potential of action in anticipating and seizing opportunities, this agility will not influence the SMEs performance[42].

Collaborative SMEs agility and intellectual stimulation leadership will increase creativity engagement. And finally, intellectual stimulation leadership and creativity engagement are appropriate predictors of performance of SMEs. The desire to elevate SMEs as absorbing labor, creating added value, exporting and pioneering creativity and innovation is becomes the most priority factor of the assumption that only MSEs with superior growth can be sustainable and inclusive at the same time. Opportunities for progressive advancement of SMEs were opened by new technologies, new business models, increases in human capital stock, and very strong urgency to reduce social economic inequality between citizens, between regions or regions and between generations. To maintain the SMEs performance, SMEs must engage their recourses creativity potentials and make them as their strategic asset to make new producs, new innovations and bring new changes in the organization. The next factors improving the SMEs performance is how the leader stimulate the human capital to improve their intellectual capacity to answer the challenge of the businesse environtment dynamic changes. However, overall the changes above are a good opportunity to elevate SMEs to a more symbiotic position.

\section{LIMITATION AND FUTURE RESEARCH AGENDA}

This study also has clear managerial implications. The results reveal that, to enhance SMEs performance, organizations ought to improve their creativity process engagement. Although the importance of intellectual stimulation leadership as an antecedent of SMEs performance has gradually gained recognition, how to develop and to put such finding into practice still remains uncertain. The results suggest that SMEs leader should foster and deploy the firm's creativity engagement mechanisms to effectively maximize the impact of agility on achieving SMEs performance. This study tests the predictive validity of the model, providing practitioners with a powerful tool for SMEs management to face the dynamic environments. Further developments of this model can provide a practical guide to increase the level of collaborative agility, which is essential to improve the competitive position of SMEs and to ensure their survival in the current uncertain conditions.

\section{CONCLUSION}

Collaborative agility does not have a significant effect on SMEs Performance Improvement, Collaborative agility will enhance the SMEs performance through creativity engagement.

Collaborative agility is found to be a trigger on creativity engagement. How the leader stimulate their human capital intellectual capacity will increase the creativity engagement and performance. How the SMEs engage their creativity process will make the differences in produce their products to meet the customers needs.

This study found two model of improving the SMEs performance, the first model found is organizations must increase the collaborative agility trough creativity engagement of their human capital to improve the performance. The second SMEs performance improvement model is increasing the intellectual stimulation leadership and creativity engagement in creating the best performance.

\section{REFERENCES}

[1] Lies M. Hamzah And D. Agustien, "Pengaruh Perkembangan Usaha Mikro, Kecil, Dan Menengah Terhadap Pendapatan Nasional Pada Sektor Umkm Di Indonesia," J. Ekon. Pembang., Vol. 8, No. 2, Pp. 215-228, 2019.

[2] A. Hapsari And D. Iskandar, "Analisis Faktor-Faktor Yang Mempengaruhi Pertumbuhan Ekonomi Provinsi Jawa Tengah," Ekon. Pembang., Vol. 18, No. 1, Pp. 219-227, 2018.

[3] D.-I. Shin, "An Exploratory Study Of Innovation Strategies Of The Internet Of Things Smes In South Korea," Asia Pacific J. Innov. Entrep., Vol. 11, No. 2, Pp. 171-189, 2017, Doi: 10.1108/Apjie-08-2017-025.

[4] C. Curado, L. Muñoz-Pascual, And J. Galende, "Antecedents To Innovation Performance In Smes: A Mixed Methods Approach," J. Bus. Res., Vol. 89, No. December 2017, Pp. 206 215, 2018, Doi: 10.1016/J.Jbusres.2017.12.056.

[5] Yunan, "Analisis Faktor-Faktor Yang Mempengaruhi Pertumbuhan Ekonomi Indonesia," Anal. Fakt. Yang Mempengaruhi Pertumbuhan Ekon. Indones., Pp. 1-83, 2009.

[6] M. Á. Rodríguez-Serrano And E. Martín-Armario, "BornGlobal Smes, Performance, And Dynamic Absorptive Capacity: Evidence From Spanish Firms," J. Small Bus. Manag., Vol. 57, No. 2, Pp. 298-326, 2019, Doi: 10.1111/Jsbm.12319.

[7] O. Malca, J. Peña-Vinces, And F. J. Acedo, "Export Promotion Programmes As Export Performance Catalysts For Smes: Insights From An Emerging Economy," Small Bus. Econ., No. 1, 2019, Doi: 10.1007/S11187-019-00185-2.

[8] B. M. Bass, "Leadership: Good, Better, Best," Organ. Dyn., Vol. 13, No. 3, Pp. 26-40, 1985, Doi: 10.1016/00902616(85)90028-2.

[9] Y. Cho, M. Shin, T. K. Billing, And R. S. Bhagat, 
"Transformational Leadership, Transactional Leadership, And Affective Organizational Commitment: A Closer Look At Their Relationships In Two Distinct National Contexts," Asian Bus. Manag., Vol. 18, No. 3, Pp. 187-210, 2019, Doi: 10.1057/S41291-019-00059-1.

[10] J. Odumeru And G. Ifeanyi, "Transformational Vs. Transactional Leadership Theories: Evidence In Literature," Int. Rev. Manag. Bus. Res., Vol. 2, No. 2, Pp. 355-361, 2013.

[11] B. M. Bass And B. J. Avolio, "Multifactor Leadership Questionnaire (Mlq)," Mind Gard., Pp. 1-114, 2000.

[12] A. C. Peng, H. E. Lin, J. Schaubroeck, E. F. Mcdonough, B. Hu, And A. Zhang, "Ceo Intellectual Stimulation And Employee Work Meaningfulness: The Moderating Role Of Organizational Context," Gr. Organ. Manag., Vol. 41, No. 2, Pp. 203-231, 2016, Doi: $10.1177 / 1059601115592982$.

[13] B. N. Smith, R. V. Montagno, And T. N. Kuzmenko, "Transformational And Servant Leadership: Content And Contextual Comparisons," J. Leadersh. Organ. Stud., Vol. 10, No. 4, Pp. 80-91, 2004, Doi: 10.1177/107179190401000406.

[14] T. Betts And S. K. Tadisina, "Supply Chain Agility, Collaboration, And Performance: How Do They Relate?," Poms 20th Annu. Conf., Pp. 1-22, 2009.

[15] C. Conversations, "Publishing \& Digital Culture: Agility, Community, Collaboration," 2018

[16] R. Hoda, J. Noble, And S. Marshall, "Agile Undercover: When Customers Don't Collaborate," Lect. Notes Bus. Inf. Process., Vol. 48 Lnbip, Pp. 73-87, 2010, Doi: 10.1007/978-3-64213054-0 6.

[17] I. Ozkaya, "Interact, Collaborate, Debate," Ieee Softw., Vol. 36, No. 6, Pp. 3-6, 2019, Doi: 10.1109/Ms.2019.2936955.

[18] J. B. Bear And A. W. Woolley, "The Role Of Gender In Team Collaboration And Performance," Interdiscip. Sci. Rev., Vol. 36, No. 2, Pp. 146-153, 2011, Doi: 10.1179/030801811x13013181961473.

[19] S. A. Kowo, O. A. O. Adenuga, And O. O. Sabitu, "The Role Of Smes Development On Poverty Alleviation In Nigeria," Insights Into Reg. Dev., Vol. 1, No. 3, Pp. 214-226, 2019, Doi: 10.9770/Ird.2019.1.3(3).

[20] I. Zambon, M. Cecchini, G. Egidi, M. G. Saporito, And A. Colantoni, "Revolution 4.0: Industry Vs. Agriculture In A Future Development For Smes," Processes, Vol. 7, No. 1, 2019, Doi: 10.3390/Pr7010036.

[21] V. Matinaro, Y. Liu, T. R. (Jiun S. Lee, And J. Poesche, "Extracting Key Factors For Sustainable Development Of Enterprises: Case Study Of Smes In Taiwan," J. Clean. Prod., Vol. 209, Pp. 1152-1169, 2019, Doi: 10.1016/J.Jclepro.2018.10.280

[22] S. Azim, M. T., Fan, L., Uddin, M. A., Abdul Kader Jilani, M. M., \& Begum, "Linking Transformational Leadership With Employees’ Engagement In The Creative Process.," Manag. Res. Rev., 2019.

[23] Z. An, W., Zhang, J., You, C., \& Guo, "Entrepreneur's Creativity And Firm-Level Innovation Performance: Bricolage As A Mediator.," Technol. Anal. Strateg. Manag., Vol. 30, No. 7, Pp. 838-851., 2018.

[24] C. S. Tan, X. S. Lau, Y. T. Kung, And R. A. Kailsan, "Openness To Experience Enhances Creativity: The Mediating Role Of Intrinsic Motivation And The Creative Process Engagement," J. Creat. Behav., Vol. 53, No. 1, Pp. 109-119, 2019, Doi: 10.1002/Jocb.170.

[25] Yana Du Li Zhang Yanhong Chen, From Creative Process Engagement To Performance: Bidirectional Support, Vol. 16, No. 3. 1995 .

[26] M. Stout, K. P. R. Bartels, And J. M. Love, "Clarifying Collaborative Dynamics In Governance Networks," Crit. Perspect. Int. Public Sect. Manag., Vol. 6, Pp. 91-115, 2018, Doi: $10.1108 /$ S2045-794420180000006005.

[27] Y. "Henry" Jin, S. E. Fawcett, A. D. Fawcett, And D. Swanson, "Collaborative Capability And Organizational Performance: Assessing Strategic Choice And Purity," Int. J. Prod. Econ., Vol. 214, No. February, Pp. 139-150, 2019, Doi: 10.1016/J.Ijpe.2019.04.006.
[28] H. Nold And L. Michel, "The Performance Triangle: A Model For Corporate Agility," Leadersh. Organ. Dev. J., Vol. 37, No. 3. Pp. 341-356, 2016, Doi: 10.1108/Lodj-07-2014-0123.

[29] K. Matzler, E. Schwarz, N. Deutinger, And R. Harms, "The Relationship Between Transformational Leadership, Product Innovation And Performancein Smes," J. Small Bus. Entrep., Vol. 21, No. 2, Pp. 139-151, 2008, Doi: 10.1080/08276331.2008.10593418.

[30] I. Weller, J. Süß, H. Evanschitzky, And F. Von Wangenheim, "Transformational Leadership, High-Performance Work System Consensus, And Customer Satisfaction," J. Manage., Vol. Xx, No. X, Pp. 1-29, 2019, Doi: 10.1177/0149206318817605.

[31] N. Nahum And A. Carmeli, "Leadership Style In A Board Of Directors: Implications Of Involvement In The Strategic Decision - Making Process," J. Manag. Gov., No. 0123456789, 2019, Doi: 10.1007/S10997-019-09455-3.

[32] I. Sánchez-Cardona, M. S. Soria, And S. Llorens-Gumbau, "Leadership Intellectual Stimulation And Team Learning: The Mediating Role Of Team Positive Affect," Univ. Psychol., Vol. 17, No. 1, Pp. 1-16, 2018, Doi: 10.11144/Javeriana.Upsy171.List.

[33] K. Jaskyte, "Transformational Leadership, Organizational Culture, And Innovativeness In Nonprofit Organizations," Nonprofit Manag. Leadersh., Vol. 15, No. 2, Pp. 153-168, 2004, Doi: 10.1002/Nml.59.

[34] T. T. Nguyen, L. Mia, L. Winata, And V. K. Chong, "Effect Of Transformational-Leadership Style And Management Control System On Managerial Performance,” J. Bus. Res., Vol. 70, Pp. 202-213, 2017, Doi: 10.1016/J.Jbusres.2016.08.018.

[35] M. Cheng, C., \& Yang, "Creative Process Engagement And New Product Performance: The Role Of New Product Development Speed And Leadership Encouragement Of Creativity.," J. Bus. Res., Vol. 99, Pp. 99, 215-225., 2019.

[36] I. Buil, E. Martínez, And J. Matute, "Transformational Leadership And Employee Performance: The Role Of Identification, Engagement And Proactive Personality," Int. J. Hosp. Manag., Vol. 77, No. June, Pp. 64-75, 2019, Doi: 10.1016/J.Ijhm.2018.06.014

[37] F. Manzoor, L. Wei, M. Nurunnabi, Q. A. Subhan, S. I. A. Shah, And S. Fallatah, "The Impact Of Transformational Leadership On Job Performance And Csr As Mediator In Smes," Sustain., Vol. 11, No. 2, Pp. 1-14, 2019, Doi: 10.3390/Su11020436.

[38] C. Cheng And M. Yang, "Creative Process Engagement And New Product Performance: The Role Of New Product Development Speed And Leadership Encouragement Of Creativity," J. Bus. Res., Vol. 99, No. February, Pp. 215-225, 2019, Doi: 10.1016/J.Jbusres.2019.02.067.

[39] Z. Ou, T. Chen, F. Li, And P. Tang, "Constructive Controversy And Creative Process Engagement: The Roles Of Positive Conflict Value, Cognitive Flexibility, And Psychological Safety," J. Appl. Soc. Psychol., Vol. 48, No. 2, Pp. 101-113, 2018, Doi: 10.1111/Jasp.12494.

[40] R. Schechner, "Performance Theory," In Asian Theatre Journal, 2013, Vol. 30, No. 2, Pp. 276-294, Doi: 10.1353/Atj.2013.0047.

[41] K. B. Lasater, O. F. Jarrín, L. H. Aiken, M. D. Mchugh, D. M. Sloane, And H. L. Smith, "A Methodology For Studying Organizational Performance: A Multistate Survey Of Front-Line Providers," Med. Care, Vol. 57, No. 9, Pp. 742-749, 2019, Doi: 10.1097/Mlr.0000000000001167.

[42] A. Harraf, I. Wanasika, K. Tate, And K. Talbott, "Organizational Agility," J. Appl. Bus. Res., Vol. 31, No. 2, Pp. 675-686, 2015, Doi: 10.19030/Jabr.V31i2.9160.

[43] C. M. Felipe, J. L. Roldán, And A. L. Leal-Rodríguez, "An Explanatory And Predictive Model For Organizational Agility," J. Bus. Res., Vol. 69, No. 10, Pp. 4624-4631, 2016, Doi: 10.1016/J.Jbusres.2016.04.014.

[44] L. Ngo-Ye And M. Ahsan, "Enterprise It Application Systems Agility And Organizational Agility," Assoc. Inf. Syst. - 11th Am. Conf. Inf. Syst. Amcis 2005 A Conf. A Hum. Scale, Vol. 2, Pp. 885-889, 2005. 